\title{
PSYCHOLOGY OF AUTHOR IN "ANNE OF GREEN \\ GABLES” NOVEL WRITTEN BY LUCY MAUD \\ MONTGOMERY
}

\author{
Arfiani, Indah Wardaty Saud \\ English Literature Department, Cultural Sciences Faculty, \\ Muhammadiyah University of Gorontalo
}

\begin{abstract}
The objective of this research is to analyze the psychology of Lucy Maud Montgomery as a write which is reflected in her novel entitled Anne of Green Gables. The technique of collecting data is data documentation technique that is a record of events that has passed. The documentation covers the content of Montgomery's novel and her biography. The approach in analyzing the novel is psychological approach. The result is Lucy Maud Montgomery as the author and Anne as the main character in the novel have imaginative personality which belong to practical imaginative type, has desire to be appreciated, and loneliness. Besides, loneliness gives the impact towards Lucy Maud Montgomery in creating her personalityin writing her works.
\end{abstract}

Keywords: Psychology, Author.

\section{INTRODUCTION}

Novel generally tells about story of the characters in everyday life and all the nature. And each character has different problem. The problem that is usually described in the story is the author's experience. Many of the workers (in creating) theirs work are influenced by their personal life. Sometimes, even the characters in the works reflected their own personal characterization. In accordance toSiswanto's opinion in Dwitantyanov (2013) said that literary work is a reflection of real life in truth although reflection of real life has been compounded by imagination of the author. Literary work itself has relation with human life. Thus, it is an appropriate to use psychology as an approach in understanding human being from symptom of soul and then process into text and complete it with psychic (Endraswara, 2003). The selection of the words shows the characteristic for every each author. Freud in Andriyanti (2016) desrcibes the author in creating 'attacked' illness called 'neurosis' sometimes even reached the stage of 'psychosis' such as the mental nerve and pain which made it under very depressed (not defined in the conditions of insane), lamented the consequences of 
ideas and the idea of a tempestuous wants channeled in the form of creation of literary work.

Anne of Green Gables novel is a work written by a Canadian author named L. M. Montgomery in 1908. This novel was being her first work which made her name known by many people. A novel which tells about an orphan little girl named Anne Shirley who arrived in Avonlea caused by confusion. Her arrival actually was not expected by a sibling named Matthew Chutbert and Marilla. Actually they wanted a little boy, not a girl, to become custody. A boy can help them in take care of Green Gables better than a girl. But who can guess, this is a best fallacy for them. In truth, this little girl with all her imagination have endearing them both.

When they decided to take care of her, they try to give their best service although they both had never experienced taking care of a child. Because this is the first time for them, they won't make it meaningless. They sent her to the school, giving her motivation and advices as like parents. Anne who has a romantic soul, was always touched with every kindness toward her. It's long time she never get treat like that. For every kindness she got she tried to do her best for them, her lovely parent custody. She want to make them both proud of her.

Lucy M. Montgomery as the author of this novel really has made the readers loves Anne as the main character in the novel. The story of Anne who since her childhood has never felt the affection of her parents made her more patients facing her life. For several times, since she was a little girl before and finally staying at Green Gables in the care of brother and sister Matthew and Marilla, moving residence until eventually no more families who want to take her and should be settled in the orphanage. The story of Anne as the main character in this novel has similarity with Montgomery's life story.

\section{RESEARCH METHOD}

Based on the problem statement and the objective of this research, researcher used descriptive qualitative method to describe or to analyze a result of research but not to use to make conclusion extensively (Sugiyono in Widjaja, 2013). 
Source of data in this research consist of two categories primary data and secondary data. The primary data source in this research is novel entitled Anne of Green Gables written by Lucy Maud Montgomery, and the secondary data source of this research is taken from psychology of literature books, journal psychology, and internet.

Technique of collecting data is documentation. Documentation technique according to Sugiyono in Trianto (2015) is a record of events that has passed. Document can be in the form of text, images, or the works a monumental. In literary work especially novel included in form of text. Document that form of writing for example diaries, life histories, stories, biographies, regulations, policies. Studies document is complementary to the use of the method of observation and interviews in qualitative research. Documenting contains the information can be taken from the written sources or in the place of respondent. The documentation in this research is Montgomery's novel entitled Anne of Green Gablesand her biography. In analyzing the data, the the researcher uses three techniques of analyzing data according to Miles and Huberman in Adiputra (2011) those are: firstly, Data reduction, it means to the researcher to make summary, focus on the important things, find out the theme and the pole, and remove unnecessary things. On this step the researcher identified and classified the data in the novel by choosing the important things related with the author's experienced in her biography concern on the impact of her psychology in creating her personality by applying related approach. Secondly, Data Display. The thing that researcher done in this second step is interpreting. In this research, the researcher interprets and describes the data aspect of psychology of the author Lucy Maud Montgomery which is reflected in her novel Anne of Green Gables. Thirdly, Verification or drawing conclusion. In this step concludes the result of this research. The researcher verified by elaborating the data with theories of psychology and the Author biography, and then drew the conclusion as the result of the research. 


\section{RESEARCH FINDING AND DISCUSSION}

Based on the research, the researcher finds some data related to the psychology of Montgomery reflected in her novel Anne of Green Gables through the main character Anne, those are; imaginative, have desire to be appreciated, and loneliness that have the impact toward her habit.

\section{Imaginative}

Imagination consist in reproducing the contents of past experience and then arranging in a new order different from that in which they were originally experienced. And memory is the exact reproduction of the contents of past experience. In addition, Imagination has several types, and appropriate with data finding about imaginative, found that imaginative here included in practical imaginative type. According to Panchal (2016) practical imagination or called pragmatic imagination is one of the types of imagination that involved in practical construction and the practical construction itself controlled by objective condition. Practical imagination found in this novel Anne ofGreen Gables showed on the main character Anne Shirley and its reflection by Montgomery. It can be seen on the data 01, data 02, data 03, data 04 and data 05. These data shows that Anne only imagines things she ever met and then imagining them as like she want. In data 01 , the author presents, the imaginative character Anne indirectly through by the dialogue between the Stationmaster and Matthew briefly.Anne need a wide scope to stimulus her imagination. However, ladies waiting room its place that has little scope for imagination. She need to go to outside. In outside, she could see anything and its make her feel better. This data appropriate with the definition of practical imaginative that the practical construction controlled by objective condition.

Moreover, in data 02 Anne did practical imagination while waiting Matthew arrives from Green gables to pick her up. She imagine perhaps Matthew have happened prevent made him not coming yet. This imagines controlled by her condition at the time. She may think like that because at the time, Anne has arrived and Mathew came so late. Then she begun imagine that something happen 
with her. Memory is become the exactly reproduction of the content of past experience that formed the imagination (Panchal, 2016). From the explanation, memory in imagination describes in data 03, here Anne memories the asylum people and begun imagine them. She imagines that perhaps asylum people were really the daughter of a belted earl who had been stolen away from her parents. In addition, Practical imaginative also described in this data. In this data, she imagines herself as like she want. Anne is the skinny little girl and she thought that was dreadful. Then, Anne imagines she has a plump and full body, with sweets dents like as dimple in her elbow.

Imagine things as like she want also describe in data 04 Anne is presented worn a horrid old wincey dress when she left the asylum and she felt very embarrassed worn the dress. She tells about what are on people mind when they're looking at her. She feels the people pitied on her. Then here Anne begun imagine that she had worn the most beautiful pale blue silk dress and she worn a big hat all flowers and nodding plums, and worn a gold watch, and kid gloves and boots. Besides in three previous data, practical imaginative also can be seen in the data 05 Anne loves trees. Here is Anne talking about trees at asylum. She imagines that the trees at the asylum as like orphans. They must go live outside from the asylum to get better live. Furthermore, the last data describes practical imagination found in data 06 . In this data, she utilizes her imagination to passing her difficulties. In her data Anne was in the healing process. Her foot was break, and she can't go out to play, and have to stay at home until heal.

From these explanation data findings above can be concluded that the main character in this novel "Anne of Green Gables" here has psychology type practical imaginative, that is always imagine things that she want based on her condition. And this is reflects on the author, Lucy Maud Montgomery. Imaginative Montgomery can be seen from her biographical in encyclopedia (2010) "Young Maud was a solitary child, imaginative..." she experienced when at the time she lived with her maternal grandparent house'. In the other sources about Montgomery's life in journal written by Gillen (1976) "her childhood was a 
lonely one, spent in the home of an aged and sever couple, but she took consolation in the natural beauty of the countryside in her own fertile imaginative world".

This is supporting the data finding, because here is described that Montgomery experienced several repressed in her life; cause of her mother had died, and education style from her maternal grandparent in unforgiving manner. In this case, that become the causes of Montgomery becomes an imaginative individual. As the function of this practical imaginative type, All of that gives fulfill practical need of her life (Panchal, 2016).

\section{Desire to Be Appreciated}

Every individual wants and needs to feel valued for who they are and recognized for their contributions and accomplishment to know that they have made a difference in someone's life. Appreciation is acknowledging the value and meaning of something; an event, a person, a behavior, an object and feeling positive emotional connection to it (Adler and Fagley, 2005. p.81). Express an appreciation can boost the spirit, passion, and purpose (Smith, 2010). In Lucy Maud Montgomery's novel entitled Anne of Green Gables presented several expressions about appreciation to the main character, Anne. It can be seen in data 11 , and data 12.

Data 11, Anne got an appreciation from the doctor of her ability in handle a baby who got cough in exactly ways. Appreciation in this data did not inform to her directly, but this is enough to make people know that Anne a little girl who they thought is a stranger with her head that full of imagination have hidden ability. The impact of appreciation of the data 11 also can be described in the data 12. She got an invitation from Mrs. Barry to tea with her family at her home as Mrs. Barry's greetings caused Anne helped her child. At the time Mrs. Barry used hers special cup for tea and Anne was the first girl who used that cup. This appreciation gives her energy and motivation to work harder and do more, although she knows that she never released make troubles but she will always try hard for it. Compare with Montgomery's life and Anne Shirley. Montgomery's 
childhood must to follow the roles of her grandparent. She was not a naughty girl, she was an obedient girl. But everything she did, never get appreciated. That's feeling like nobody care with her. Then she tried new things and hope that will make her family proud of her; wrote poems, wrote as essay and joined essay contest. But they did not support her while her family from her grandparent and her step-mother. But that was not made her down. She begun has big ambition for it.

When she was sixteen years old Montgomery would like to joined teachers training course at Charlottetown. Same thing happened for her grandfather but not with her grandmother and her father. Her grandfather Macneil was unwilling to pay Montgomery. However, this was still made her felt aimless. In her diary alludes to battles of will with her sharp-tongued of grandfather.

At the end of this year Montgomery's grandmother and father putting together enough money to send her off to Prince of Wales College in Charlottetown. And she was study hard for it. She did very well in her final exams and had the honour of reading an essay on Shakespeare's Portia at the spring commencement exercises. Montgomery had crowded a two-year curriculum at Prince of Wales College into a single year. She concentrates on finding a paying job as a school teacher. Grandfather Macneil never changes his mind for Montgomery. She got no such encouragement from her grandfather; she could only apply to nearby schools or ones. When enough money rewarded her efforts she could plan a year of university in spite of her grandfather's disapproval. Her grandmother offered to cover halff the cost of year at Dalhousie University, in Halifax, Nova Scotia.

Montgomery has a strong soul. Had no appreciation from her grandfather made her pushed her to do better things. Although her grandfather died, makes her sad. However she loves her grandfather. She back to the island with at least halfhearted hopes. In her journal she wrote that she was growing more and more engrossed in her writing "nearly everything I think or do or say is subordinated to a desire to improve in my work". 
From the explanation data above it can be concluded that Anne Shirley as the main character got appreciation that made her shoved to do more her best, but Montgomery didn't. But it does not mean that Anne Shirley was not a reflection of Montgomery who got appreciation. Montgomery who was lack of supports and need appreciate from her family, made her evolved to do more and more the best things in her life toget appreciation.

\section{Loneliness}

Farooqi (2015) loneliness is the unpleasant feeling due to inability to have satisfying relationship or the dissatisfaction with one's quality of relationship. Being alone doesn't meant she/he is lonely, on the contrary loneliness can be feel when someone with her/his friends. That's as like what's Anne feels. Before stayed at Green Gables, she lived with her parent custody, and then lived at asylum. There were many people around her; she could make relationship with them if she wants. But she won't it. It was not caused she unable to communicate with them, but they were not who in Anne wishes to get a better social relationship.

Findings about loneliness can be seen in data 09, data 10 and data 11. Loneliness has many possible causes one of that it's feeling to be owned. Data feeling to be owned in this novel Anne of Green Gables can be seen in data 10. In data 09 Anne was so pleasant because there was someone wanted her and she will belong of them. She felt lonely, in spite of there was many people at the asylum. In this data can be seen that her loneliness caused her unpleasant feeling in satisfying relationship with other. There are many people at the asylum and she just only made a friend with her.

Moreover, feeling loneliness Anne described in data 10. In this data she got better relationship as she wished. She has many friends and has a best friend too; she called it "soulmate". This is making her feel satisfied.

In addition, feeling loneliness also founded in data 11. Anne felt disconnected with her friends caused she couldn't be best friend with Diana anymore. Although she has many friends, but she felt that nobody can't understand and love her as her 
best friend did, Diana. And also similarities between Diana and her that nobody of her friend have it. Lonelines in this data is feeling of social disconnecteness in which Anne wishes that she had better social relationship. Besides, except got lonely, she was also need feeling to be owned from her parent custody. Faction in the relationship and it will causes the loneliness turn up. So here, in data 10 present that Anne need to avow that she is theirs, so she can feels that she is also a part of this family. She wants to call Marilla as "Aunty" but Marilla won't it. She thought at least with the expression can make she really belong to Marilla. However, characteristic of loneliness Anne as the reflection of Montgomery also found in her biography. Montgomery's childhood was very lonely. Has family but the felt like they were not for her. After her mother died, by her father he left Montgomery with her maternal grandparent who was severing. She became friend only with her cousin (Rubioand Waterson, 1995. p. 18) but they were not close.Her lonelinesss caused the treatments and attitudes of her family.

Montgomery got less love from her family. But Montgomery could utilize her loneliness with imagining; make her ideal world and writing. "In the face enormous trials, Montgomery held onto that strand. She used to knot together all of her puzzling experience, creating memorable, lovable stories with sunny surfaces and darker shadows. Whatever happened to her, whatever she read or herd she caught in a net of word" (Rubio and Waterston, 1995. p. 11).

In addition there is a data that support the finding data that states Montgomery was a lonely girl. Montgomery family life with her dear father and petty stepmother was infuriating. Her stepmother named Marry Ann was far from the loving, protective mother Maud had yearned for, who found herself turned into a baby-minding drudge, often kept home from school (Rubio and Waterston 1995.p. 22).

Loneliness individual is caused by the unpleasent or dissatisfying in relationship with other. They have difficulty to communicate with other. So they possible to find out express what they are feeling. They usually write what they feel in diary. For some people this is become their hobby next day. It is like what 
the author has been experienced. Besides showing imaginative personality's Anne, her loneliness and feeling to be owned, desire to be appreciated, Montgomery also created that Anne loves writing. Depiction that Anne loves writing is reflection of Montgomery. Based on finding data about writing, actually it's only Anne's passion. Other side, writing became Montgomery's way to superintend her loneliness then later becomes her passion, in this novel is different. Data showed Anne loves writing can be seen in data 13, data 14, and data 15 .

In data 13, Anne's predilection to writing appeared when she had beenstayed at Green Gables and schooled by Marilla and Mathhew. In this data describe that Anne got praise because hers composes the best ones. At the time she begun loves writing composition. Loves to be remarkable person is appeared when they asked by her teacher to wrote an essay about remarkable person. Here, she imagine how pleasant if she would be a remarkable person.

In addition, loves to writing also described in data 14 . Her personality that has practical imaginative make her felt easy to write a composition. Oftentimes she affected by her imagination. She imagined a sad story and she cried because of it. The last data which is describe the seriousness of Anne in writing. She asked her best friend to make a story club. This club facilitates her and her friends in developing their writing skill with rely on their imagination. And she will be their tutor in this club.

Writing was the important part in Montgomery's life. In whole life whatever happened to her, whatever she read or heard, she caught in a net of words (Rubio and Waterston, 1995). Montgomery's passion on writing had born when she was child. At that time this passion was to superintend her loneliness. She trained herself to write up events of her daily existence in narrative form and then entering them in a journal. Writing her secret journal became an exercise in narrative skill. She recorded certain experiences of her life. Moreover, Montgomery learned her narrative skill from the traditional storytellers, male and female, in her clan at the church other tricks of the trade she learned from her 
favorite novelists. Know that her life was unpleasant and grievous. Her diary contents elude her grandfather. Not only that, many of poems, novels contain hidden rebellion, her journals pulse with open resistance, resentment, and depression (Rubio and Waterston, 1995).

\section{CONCLUSION AND SUGGESTION}

\section{Conlusion}

Based on the research, it can be concluded that the main character in the novel "Anne of Green Gables" reflects the life of its author, Lucy Maud Montgomery. In this case, the researcher analyzed the psychology of the author as reflected in the main character. The researcher found some psychological aspects reflected psychology of the author on the main character Anne Shirley, those are; practical imaginative personality, has desire to be appreciated and loneliness and loves writing. Love writing actually just her way to cope her loneliness.

Montgomery has practical imaginative personality; this is one of the types of imagination. This Imagination controlled by its condition. Moreover, Montgomery was a lonely girl. When she was child she lived with her grandparents who were severe. Her life was very tragic and loneliness. In addition, those feelings were caused by her family bad treatments. She got less love from her family. And Writing was her passion as long as that time. Because in writing she can write everything happened in her life; she heard, she read, she putted in her diary. At least she became one of the best and famous writers at the time. Her work novel Anne of Green Gables has made hers name known by many people.

\section{Suggestion}

After analyzing Montgomery's novel entittled “Anne of Green Gables”, the researcher proposed some suggestion for anyone who want to analyze novel, first of all; to study and understanding theory and kind of approaches in analyzing literary work. Because having a good understanding aboutthat will make you easy in doing the analysis. In addition, researcher also has to find the reference related to the research, and consult it with the advisor who will read the result of the 
researcher's work and revise it. Finally, the writer hopes that, this research can be useful for the next researcher as the reference.

\section{REFERENCES}

Adler, M, G. And Fagley, N, S. 2005. Appreciation: Individual Difference in Finding Valueand Meaning as a Unique Predictor of Subjective Well-Being.

Andriyanti, Y. 2016. PeranPsikologidalam Proses KreatifPenciptaanKaryaSastra.

Dwitantyanov, Aswendo. 2010. UnsurPsikologidalamPengarang.

Endraswara, Suwardi. 2003.MetodologiPenelitianSastra: Epistemologi, Model, Teori, danAplikasi. Yogyakarta: PustakaWidyatama.

Trianto, M. 2015. MetodePenelitianMenurutSugiyono (2013).

Farooqi, Saif. 2015. Life and Psychology.

Gillen, Mollie, The Wheel of Things: A Biography of L. M. Montgomery, Author of Anne of Green Gables, London: Harrap, 1976.

Panchal, Garima. 2016. Imagination: Meaning, Nature, and Types Psychology.

Rubio, Mary. and Waterston, Elizabeth. 1995. Writing A Life L.M. Montgomery.

Trianto, M. 2015. MetodePenelitianMenurutSugiyono (2013).

Widjaja, Ivan. 2013. MetodePenelitian. 